\title{
Age, growth and fishery biology of cichlid spp. in Abu-Zaabal Lakes, Egypt
}

\author{
Kariman A. Shalloof and Alaa M. El- Far \\ National Institute of Oceanography and Fisheries, \\ 101Kaser El-Eini St., Cairo, Egypt
}

\begin{abstract}
The present investigation aimed to study species composition, condition factor, growth and feeding habits of Orechromis niloticus (Linnaeus, 1758), Orechromis aureus (Steindachner, 1864), Tilapia zillii (Gervais, 1848) and Sarotherdon galilaeus (Linnaeus, 1758) in Abu- Zaabal Lakes, Egypt. The abundance of different species was seasonally fluctuated. It was found that $O$. aureus is the most common species constituting about $50.0 \%$, followed by $S$. galilaeus, while $O$. niloticus ranked as the $3^{\text {rd }}$ species in the total catch. The highest value of the exponent " $b$ " of length-weight relationship and condition factor "K" was recorded for T. zillii and the lowest for O. aureus. The valve of $(\mathrm{K})$ was inversely related to the size of $O$. aureus and $O$. niloticus, and tends to be fairly constant in T. zillii and S. galilaeus. All cichlid species attained their highest growth rates in length during the first year of life, after which a gradual decline was noticed with further increase in age. O. niloticus had the highest growth rate than the other three species. The parameters of Von Bertalanffy growth model were estimated as $\mathrm{L}_{\infty}=34.59,45.23,39.88$ and $30.65 \mathrm{~cm}$ while, $\mathrm{k}$ $=0.1336,0.074,0.0873$ and $0.1692 \mathrm{y}^{-1}$ and $\mathrm{t}_{\mathrm{o}}=-2.09 ;-2.49 ;-2.01$ and -0.75 year for $O$. niloticus, O. aureus, T. zillii and S. galilaeus, respectively. Gut analysis of $O$. aureus, $T$. zillii and S. galilaeus revealed that the major food items were detritus, diatoms, green algae, animal derivatives, sand particles and rotifers.
\end{abstract}

Key words: Abu- Zaabal Lakes, O. niloticus, O. aureus, T. zillii, S. galilaeus, age, growth, feeding habits.

\section{INTRODUCTION}

Abu - Zaabal lakes consist of three man-made ponds (A, B and C), inland closed basins, formed by the fracture and extract the Basalt rocks. The depths are ranged between $6-25 \mathrm{~m}, 1-7 \mathrm{~m}$ and $1-5 \mathrm{~m}$ for the ponds $\mathrm{A}, \mathrm{B}$ and $\mathrm{C}$, respectively. The ponds receive their water from the ground and seepage water. They lie at $35 \mathrm{Km}$ northeast of Cairo (Fig.1). They cover an area of $608.050 \times 10^{3} \mathrm{~m}^{2}$, and occupy the area between Latitudes $30^{\circ} 16.62$ and $30^{\circ} 17.5 \dot{8}$ $\mathrm{N} \&$ Longitudes $31^{\circ} 20.90$ and $31^{\circ} 21.69 \mathrm{E} \mathrm{(Abd} \mathrm{-} \mathrm{Ellah,} \mathrm{2003;} \mathrm{Abdo,} \mathrm{2005).}$

The natural fishery resources in Egypt are declining, so there is a need to considerably increase seafood production through safe and high-quality fishery products to bridge the widening gap between demand and supply (EL-Gawady, 
2002).Thus, much attention must be given to develop the fishery of Abu-Zaabal Lakes. Several studies have been carried out on these lakes and lights were thrown on morphometry and bathymetry (Abd-Ellah, 2003), physico-chemical characteristics (Abdo, 2005), pathological conditions of Tilapia zillii (El-Mansy, 2005), phytoplankton composition (Mohamed, 2005), metals accumulation in fish organs (Mohamed and Gad, 2005), microbiological status (Rabeh and Azab, 2006), zooplankton community (El-Basset and Taylor, 2007),biological, histological and quality aspects of fish (Ibrahim et al. 2008), reproductive biology of O.niloticus, (Shalloof and Salama, 2008) and feeding habits of O.niloticus (Shalloof and Khalifa, 2009).

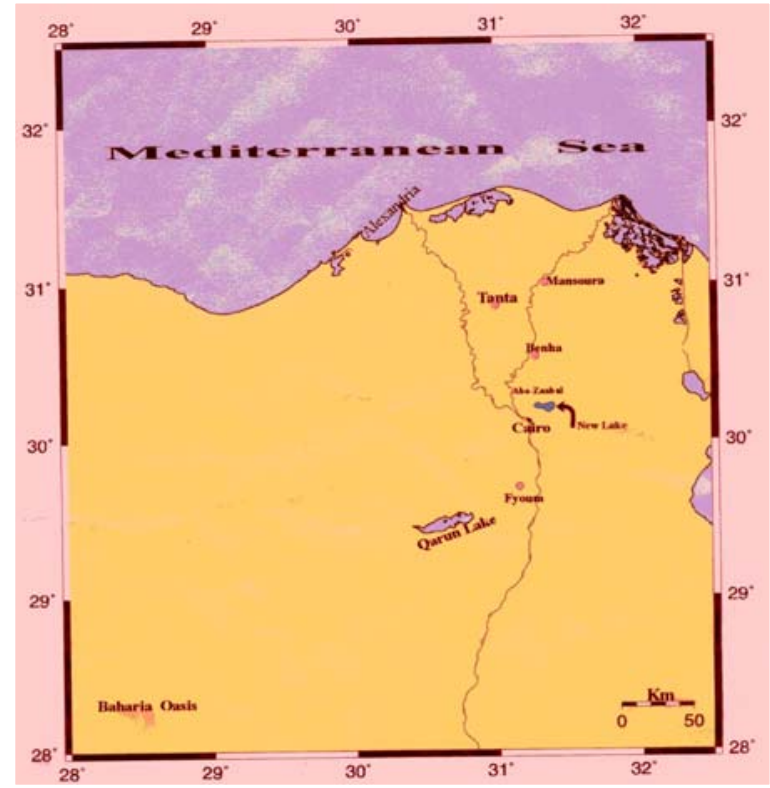

Fig. (1). Map of northern Egypt showing the location of Abu - Zaabal lakes area (arrow).

The objective of study was to provide and update information on the growth and feeding habits needed by cichlid species to flourish in these newly formed mining lakes.

\section{MATERIALS AND METHODS}

Because the commercial fishing in Abu-Zaabal Lakes was sharply declined, experimental fishing gears with the same feature of that of commercial ones were used for sampling, Fish samples were seasonally collected from the three Abu-Zaabal lakes during the period from March 2008 to February 2009. The total length and total weight of the collected fish were measured to the nearest $\mathrm{cm}$ and g, respectively. Data about gutted weight, gonad weight and liver weight; sex and stage of maturity were also obtained. 
For age determination, the scales were examined using a measuring scale projector "LEITZ T. p. 300" connected to digital micrometer spindle. Growth rate was computed by the method of Lee (1920).

Length-weight relationship was calculated by the following equation: $\mathrm{W}=\mathrm{a} \mathrm{L}{ }^{\mathrm{b}}$, where $\mathrm{W}$ is the total weight in $\mathrm{g}, \mathrm{L}$, is the total length in $\mathrm{cm}, \mathrm{a} \& \mathrm{~b}$ are constants.

Condition factor $(\mathrm{K})$ was estimated as: $\mathrm{K}=100 \times \mathrm{W} / \mathrm{L}^{3}$, where $\mathrm{W}$ is the total weight in $\mathrm{g}$ and $\mathrm{L}$ is the total length in $\mathrm{cm}$.

The Von Bertalanffy growth parameters, $\mathrm{L}_{\infty}, \mathrm{k}$ and $\mathrm{t}_{\mathrm{o}}$ were estimated. The asymptotic length $\left(\mathrm{L}_{\infty}\right)$ and the growth rate $(\mathrm{k})$ were calculated using Walford (1946) method. The time at which the growth's theoretically nil $\left(\mathrm{t}_{\mathrm{o}}\right)$ was calculated by plotting $L_{t}$ against $L_{t+1}$.

The fish stomach contents were analyzed, and the seasonal data were grouped. Analysis was done using frequency of occurrence method as described by Hyslop (1980). In above method, the occurrence of food items was expressed as percentage of the total number of stomach containing food.

\section{RESULTS}

1- Catch per unit effort: collected samples showed a sharp decrease of catch per unit effort during summer (about $5.5 \mathrm{Kg}$ per boat per day) comparable to spring season (about $35 \mathrm{Kg}$ per boat per day). Sharp decreases then occur during autumn and rise again during winter season.

2- Species composition: The fish catch from Abu - Zaabal lakes was represented by four tilapia species namely; Oreochromis niloticus, Oreochromis aureus, Tilapia zillii and Sarotheredon galilaeus. In addition the catch included specimens of Clarias gariepinus. The pooled data (by number) revealed that $O$. aureus was the most common species constituting about $50.0 \%$, followed by $S$. galilaeus $(22.0 \%)$, whereas $O$. niloticus representeds about (15.3\%) and T. zillii represented $9.0 \%$ of the total catch. The least frequent species was C. gariepinus $(5.3 \%)$. Species composition according to weight also ranked $O$. aureus as the $1^{\text {st }}$ species (about $38.4 \%$ of the total catch), whereas C. gariepinus is the $2^{\text {nd }}$ species, while T. zillii was the lowerst one (Fig. 2).
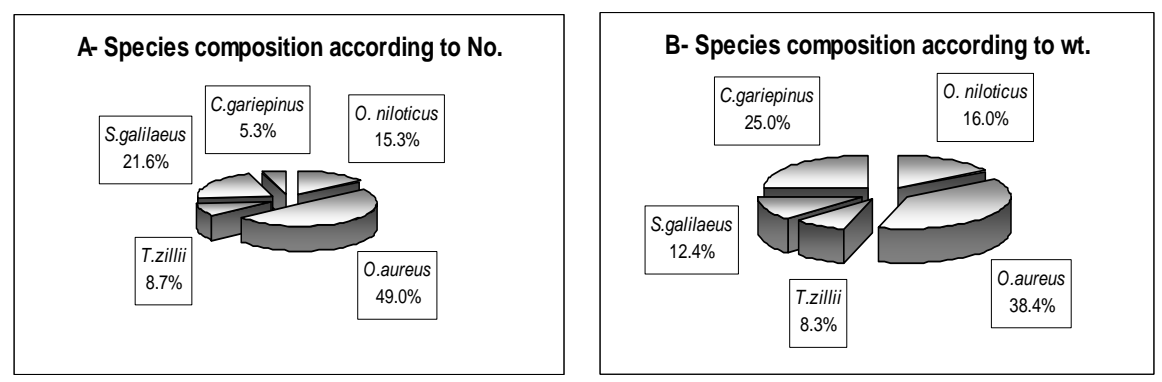

Fig. (2): Species composition of different species (pooled data) in Abu-Zaabal Lakes; A, according to number and B, according to weight during March 2008- February 2009. 
Regarding to the seasonal fluctuation in species distribution, the frequency of different species varied from season to another. O. niloticus constituted 21.5 and $12.62 \%$ of the total catch during spring and winter, respectively, while it was not represented completely in the catch during summer and autumn seasons. O. aureus was nearly the most frequent species during the four seasons. S. galilaeus was more represented during autumn and winter (36.0 and $29.44 \%$ respectively). T. zillii was highly represented during autumn and summer seasons, constituting about 24.4 and $16.8 \%$, respectively (Fig. 3).
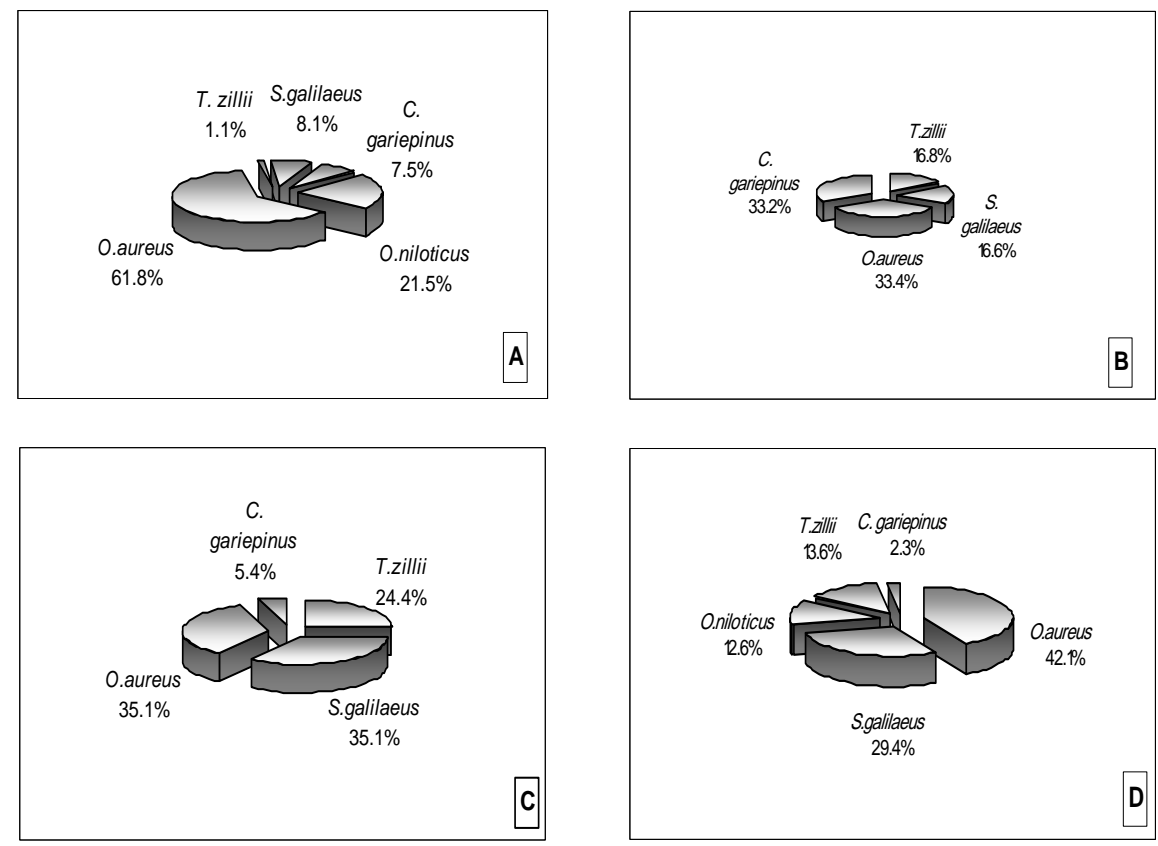

Fig. (3): Species composition of different species in Abu-Zaabal Lakes during spring (A), summer (B), autumn (C) and winter (D) season.

3- Length-weight relationship and condition factor: The total length of the fish sample in this investigation ranged from 12.0-22.0; 11.0- 19.0; 12.0-18.0; 9.0-17.0 and 26.0- 46.0 $\mathrm{cm}$ for O. niloticus, O. aureus, T. zillii, S.galilaeus and C.gariepinus, respectively .Table 1 and Figure 4 show the equation parameters of length - weight relationship. The highest value of " $b$ " was recorded for $T$. zillii $(b=3.1474)$ and the lowest one was recorded for O.aureus and C.gariepinus ( $\mathrm{b}=2.1084$ and 2.3734, respectively). 
Table (1): The values of the constants (a and b) of length-weight relationship and the relative condition factors $(\mathrm{K} \pm \mathrm{SD})$ of different species in Abu-Zaabal lakes.

\begin{tabular}{ccccc}
\hline Species & $\mathrm{a}$ & $\mathrm{b}$ & $\mathrm{r}$ & $\mathrm{K} \pm \mathrm{SD}$ \\
\hline O. niloticus & 0.0894 & 2.4034 & 0.9790 & $1.7056 \pm 0.2983$ \\
O. aureus & 0.1791 & 2.1084 & 0.9833 & $1.6610 \pm 0.2743$ \\
T. zillii & 0.0193 & 3.1474 & 0.9856 & $2.2966 \pm 0.2266$ \\
S. galilaeus & 0.0337 & 2.7588 & 0.9781 & $1.8394 \pm 0.1838$ \\
C. gariepinus & 0.0785 & 2.3734 & 0.9740 & $1.1380 \pm 0.1267$ \\
\hline
\end{tabular}
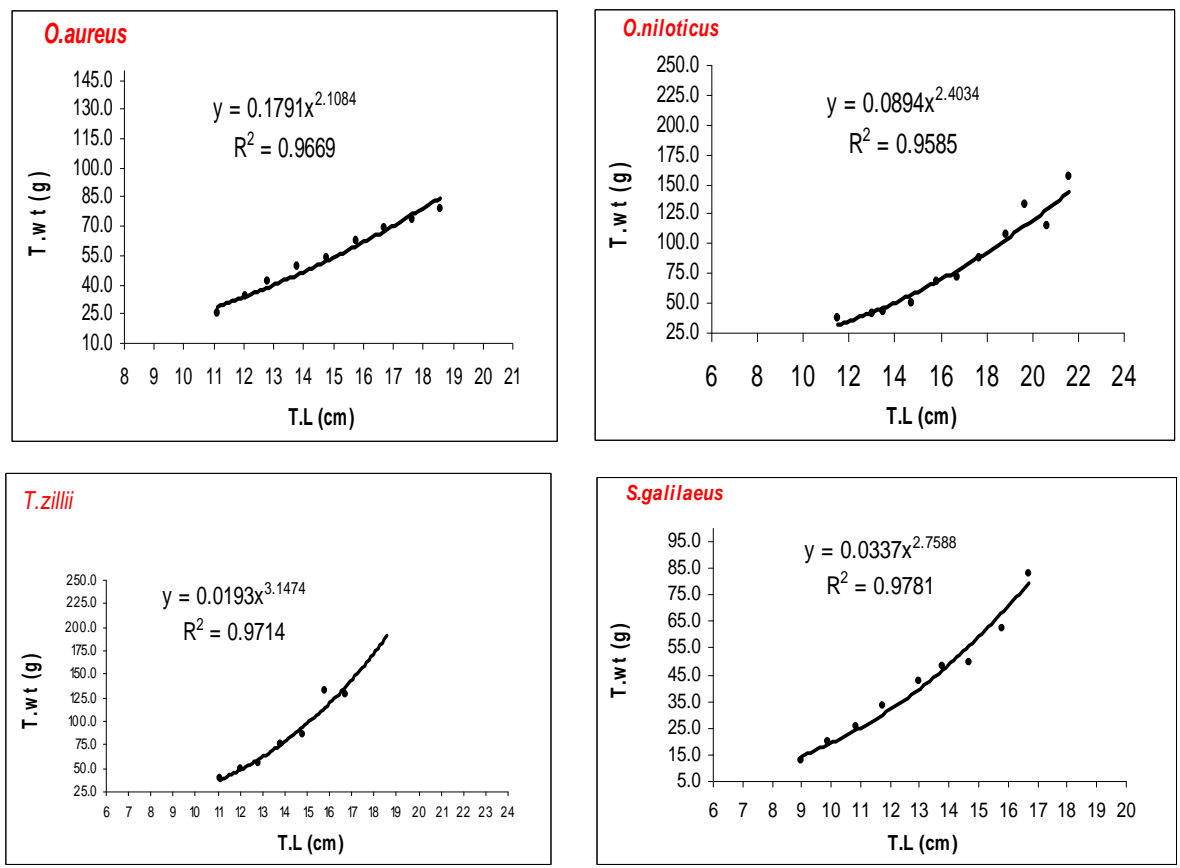

Fig. (4): Length-weight relationship of different cichlid species at Abu-Zaabal Lake during the period of investigation.

Also, the highest condition factor $(\mathrm{K})$ was recorded for T. zillii $(\mathrm{K}=$ 2.2966), whereas the lowest one was recorded for C. gariepinus and O. aureus $(\mathrm{K}=1.1380$ and 1.6610 respectively).The values of condition factor of $O$. aureus, $O$. niloticus and C. gariepinus were inversely related to the size of fish and tend to be fairly constant in small fish of T. zillii and S. galilaeus (Fig. 5) .The largest fish, C. gariepinus $(26-46 \mathrm{~cm})$ recorded the lowest mean value of condition factor (1.1380). 

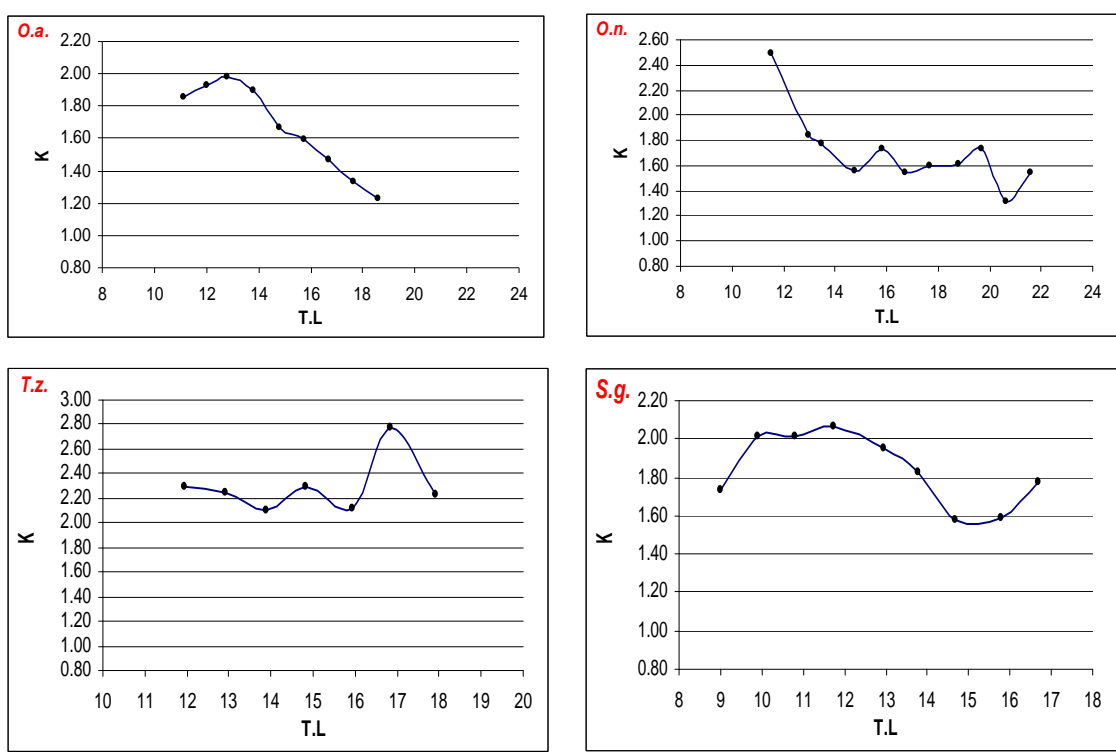

Fig. (5): Mean condition factor-mean total length relation of. O.aureus (O. a), O. niloticus (O. n.), T. zillii (T. z.) and S. galileus (S. g.) at Abu- Zaabal Lakes during the period of study

4- Age determination: In the present study, scales were used for age determination for cichlid species. The total body length (T.L.)-scale radius (Sr) of the four studied cichlids were found to be linear and could be represented by the equations in Figure 6.The recorded ages in the present study ranged from 14 years for O.niloticus, $1-3$ years for O. aureus and T. zillii and O- 3 years for $S$. galilaeus.
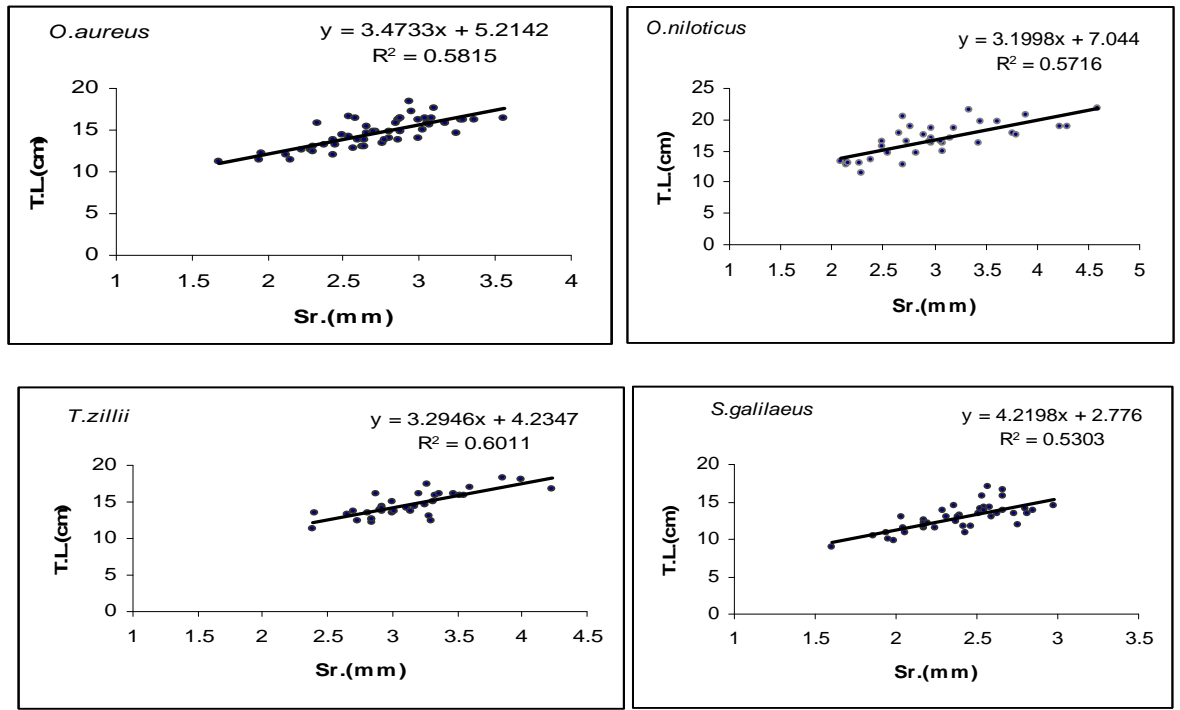

Fig. (6): Total length (T.L) - Scale radius (Sr) relationships of four cichlid species in Abu-Zaabal Lakes. 
Back- calculation and growth in length: Tables (2-5) showed the backcalculation of lengths at the end of each year of life for the four studied species. It was noticed that, each of them attained its highest growth rates in length during the first year of life, after which a gradual decrease was noticed with further increase in age. It is clear that $O$. niloticus has the highest growth than the other three species. The parameters of Von Bertalanffy growth parameters were estimated as $\mathrm{L}_{\infty}=34.59 ; 45.23 ; 39.88$ and $30.65 \mathrm{~cm} \mathrm{\&} \mathrm{k}=0.1336 ; 0.074$; 0.0873 and $0.1692 \mathrm{y}^{-1} \& \mathrm{t}_{\mathrm{o}}=-2.09 ;-2.49 ;-2.01$ and -0.75 year for $O$. niloticus, O. aureus, T. zillii and $S$. galilaeus, respectively.

Table (2): Back- calculated lengths at the end of each year of life of O.niloticus at Abu-Zaabal Lakes during the period of investigation.

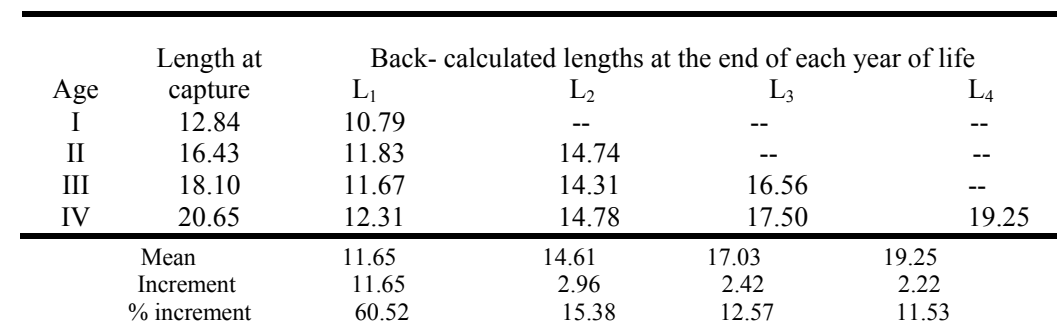

Table (3): Back- calculated lengths at the end of each year of life of O.aureus at Abu-Zaabal Lakes during the period of investigation.

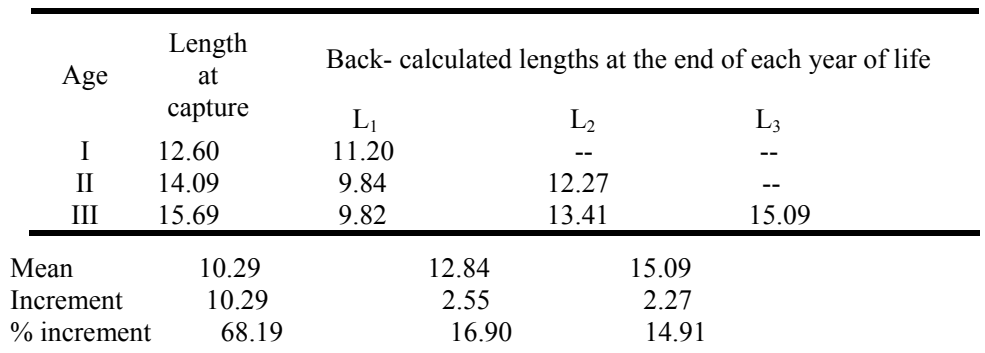

Table (4): Back- calculated lengths at the end of each year of life of T.zillii at Abu-Zaabal Lakes during the period of investigation.

\begin{tabular}{|c|c|c|c|c|}
\hline \multirow{2}{*}{ Age } & \multirow{2}{*}{$\begin{array}{c}\text { Length at } \\
\text { capture }\end{array}$} & \multicolumn{3}{|c|}{ Back- calculated lengths at the end of each year of life } \\
\hline & & $\mathrm{L}_{1}$ & $\mathrm{~L}_{2}$ & $\mathrm{~L}_{3}$ \\
\hline I & 11.95 & 9.51 & -- & -- \\
\hline II & 14.04 & 9.04 & 11.57 & -- \\
\hline III & 16.21 & 9.07 & 12.07 & 14.12 \\
\hline Mean & & & & \\
\hline Increme & & & & \\
\hline$\%$ increr & ent & & & \\
\hline
\end{tabular}


Table (5): Back- calculated lengths at the end of each year of life of S.galilaeus at Abu-Zaabal Lakes during the period of investigation.

\begin{tabular}{|c|c|c|c|c|}
\hline \multirow{2}{*}{ Age } & \multirow{2}{*}{$\begin{array}{l}\text { Length at } \\
\text { capture }\end{array}$} & \multicolumn{3}{|c|}{ Back- calculated lengths at the end of each year of life } \\
\hline & & $\mathrm{L}_{1}$ & $\mathrm{~L}_{2}$ & $\mathrm{~L}_{3}$ \\
\hline I & 11.95 & 9.51 & -- & -- \\
\hline II & 14.04 & 9.04 & 11.57 & -- \\
\hline III & 16.21 & 9.07 & 12.07 & 14.12 \\
\hline & 9.21 & & & \\
\hline rement & 9.21 & & & \\
\hline acrement & 65.23 & & & \\
\hline
\end{tabular}

5- Gut analysis: Gut analysis of O. aureus, T.zillii and S.galilaeus in AbuZaabal Lakes revealed that, the major food items were detritus, diatoms, green algae, animal derivatives, sand particles and rotifers. The ability to exploit different varieties of food makes $O$. aureus, T. zillii and S. galilaeus to be omnivorous. Diatoms were represented mainly by Navicula spp., Cyclotella spp., Achnanthes spp. and cocconies spp. Green algae were represented in fish stomachs mostly by Scenedesmus spp., Ankistrodesmus spp., Coelastrum spp., and Cosmarium spp., while blue green algae were represented by Merismopedia spp, Oscillatoria spp., Anabaena spp., Microcystis spp. and Coelospharium spp. whereas rotifers, molluscans (bivalves), cladocerans, ostracods, copepods and animal derivatives constitute the food of animal origin. It was noticed that, phytoplankton was the most common food items (Fig. 7).

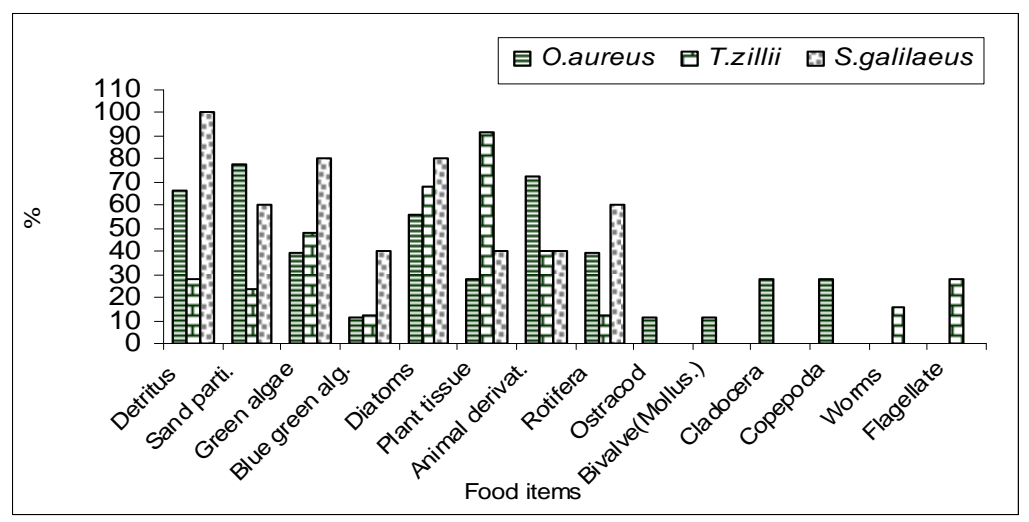

Fig. (7): Percentage of occurrence of different food items of different cichlid species in AbuZaabal Lakes.

Remains of higher plant hydrophytes were comparatively greater in $T$. zillii than O. aureus and S. galilaeus guts, since they occurred in $92.0 \%$ of the examined guts of $T$. zillii. In contrast, the organic detritus decreased considerably in $T$. zillii than in guts of the other two species. The food of animal 
origin was much frequent in stomachs of $O$. aureus than in both $T$. zillii and $S$. galilaeus. Among zooplankton, rotifers occurred in higher number of $O$. aureus and $S$. galilaeus guts (i.e. 40.0 and $60.0 \%$ respectively). Examination of the diet of these species showed that, there was high percentage of sand particles in there stomachs comprising about $77.8,60.0$ and $24.0 \%$ in the guts of $O$. aureus, $S$. galilaeus and $T$. zillii, respectively.

\section{DISCUSSION}

Since there is a growing consensus that tilapia can become the world's most important warm water cultured fishes (FAO, 1980), the present study reports on some fisheries biology as growth and abundance of natural diets needed by different cichlid species in these newly formed mining lakes to show the possibility of their usage as a big fish farm.

In the present study, $O$. aureus was the most common species, constituting about $50.0 \%$, followed by $S$. galilaeus, whereas O. niloticus ranked as the $3^{\text {rd }}$ species of the total catch. The least frequent species was $C$. gariepinus. Ibrahim et al. (2008) pointed out that O. niloticus was the most frequent species in Abu-Zaabal Lakes during 2005-2006. These differences in species composition during 2008- 2009 may be due to the change in salinity and water level of the lakes. El-Mansy (internal report, 2009) reported that, O. aureus is the least affected cichlid species by parasites in Abu-Zaabal lakes at the same time of the present study. Oviatt and Nixon (1973) found that, depth, sediment, temperature and wind speed were significant in explaining distribution of fish. Hoff and Ibra (1977) regarded temperature and salinity to be the most important factors affecting the fish fauna diversity. Amarasinghe and Samarakoon (1988) reported that, the differences in the catches of Etroplus suratensis and Tilapia rendalli were due to their restricted movements, associated with reproductive behavior. Weng (1988) found that seasonal occurrence and habitat preference of most species contribute notably to the varied catches of fish fauna. Regarding to the seasonal difference in species distribution, the frequency of different species was fluctuated from season to another. This may be correlated with variation in salinity, temperature and availability of food.

The length- weight relationship is very important for proper exploitation and management of the population of fish species (Pervin and Mortuza, 2008), and allows prediction of weight from length in yield assessment (Pauly, 1993).In fish, the weight is considered to be a function of length (Weatherley and Gill, 1987). The highest value of " $b$ " was recorded for T. zillii $(b=3.1474)$ and the lowest was recorded for O. aureus and C. gariepinus( $b=2.1084$ and 2.3734, respectively).Hile(1936) and Martin(1949) observed that the value of the regression coefficient "b" usually lies between 2.5 and 4.0 and for ideal fish $b=3$. If the fish retains the same shape, it grows isometrically and length exponent "b" has the value " 3 ",and if a value is significally larger or smaller than " 3", it shows allometric growth (Bagenal and Tesch, 1987). A value less 
than " 3 "shows that fish becomes heavier for its length as it grows (Zafar et al., 2003).The highest values of "b" revealed that the length-weight relationships of this species followed the cube law and might be affected by the general condition of appetite and gonadal contents of fish (Pervin and Mortuza, 2008).

Condition factor helps to assess the experimental improvements in an environment for an existing fish and for purpose of new stocking (Zafar et al., 2003).It is also a useful index for monitoring of feeding intensity, age, and growth rates in fish (Oni et al., 1983). It is strongly influenced by both biotic and abiotic environmental conditions and can be used as an index to asses the status of the aquatic ecosystem in which fish live (Anene, 2005).In the present study, the condition factor of $O$. niloticus, $O$. aureus and C. gariepinus was inversely related to the size of fish and tends to be fairly constant in small fish of $T$. zillii and S.galilaeus. The largest fish, C. gariepinus recorded the lowest mean condition factor $(1.1380 \pm 0.1267)$.Saliu et al. (2007) recorded that, the condition factor was inversely related to the fat and protein content and C.gariepinus had the highest mean fat and protein than Sarotherodon melanotheron, Melapterurus electricus, Synodontis clarias and Chrysichthys nigrodigitatus. No evidence that the largest Salmo salar had the highest condition factor (Johanson and Jobling, 1989).The fluctuations in relative condition factor may be due to feeding intensity, gravid condition of female or other factor (Shafi and Quddus, 1974).Condition factor of Catla catla appears to remain constant with increasing length or weight (Zafar et al., 2003). The highest condition in the present study was recorded for T.zillii and S.galilaeus (2.2966 and 1.8394, respectively). Ibrahim et al. (2008) recorded that, the best condition factor (K) was recorded for T. zillii (1.94), while the lowest was for $S$. galilaeus (1.74) in Abu Zaabal Lakes during 2005-2006. The condition factor may vary when average weight of the fish is not increasing in direct proportion to the cube of its length (Wooten, 1990).Therefore, when $b=3$, K would remain constant .If however, the weight increases more rapidly than the cube of length, $\mathrm{K}$ would increase with the increase in length. When the weight increases less than the cube of length, $\mathrm{K}$ would tend to decrease with the growth of fish (Javaid and Akram, 1972).

In the present study, all the studied cichlid species attained their highest growth rates in length during the first year of life, after which a gradual decrease was noticed with further increasing in age and O.niloticus has the highest growth than the other three species. These results are in accordance with these of Ibrahim et al. (2008) and Mahmoud and Mazrouh (2008).

The parameters of Von Bertalanffy growth model were estimated as $\mathrm{L}_{\infty}=$ $34.59 ; 45.23 ; 39.88$ and $30.65 \mathrm{~cm} \& \mathrm{~K}=0.1336 ; 0.074 ; 0.0873$ and $0.1692 \mathrm{y}^{-1} \&$ $\mathrm{t}_{\mathrm{o}}=-2.09 ;-2.49 ;-2.01$ and -0.75 year for O. niloticus, O. aureus, T. zillii and S. galilaeus, respectively. Mahmoud and Mazrouh (2008), pointed out that $\mathrm{L}_{\infty}$ of the previous studied cichlids in Rosetta branch of the Nile River were 28.5, 26.4; 16.5 and $20.3 \mathrm{~cm}$, respectively. This means that the value $L_{\infty}$ of the studied 
cichlids in the present study was greater than that recorded in the River Nile. This may be attributed to the difference in size of collected sample and the difference in ecological environment of both habitats.

The study of the food and feeding habits of freshwater fish species is a subject of continuous research because it constitutes the basis for the development of a successful fisheries management programme on fish capture and culture (Oronsaye \& Nakpodia, 2005 and Oso et al., 2006).

Analysis of guts of $O$. aureus, T. zillii and S. galilaeus(since gut content of O. niloticus in Abu-Zaabal Lake was previously studied by Shalloof and Khalifa (2009) revealed that, the major food items were detritus, diatoms, green algae, animal derivatives, sand particles and rotifers . A kind of competition may be occurring between cichlids in this ecosystem. O.aureus populations compete with S.galilaeus and the competition for food sources between these two cichlid species was demonstrated by Drenner et al. (1982) and Vinyard et al. (1987). Tissues of higher plant hydrophytes were comparatively greater in T. zillii than O. aureus and S. galilaeus guts, since they occurred in $92.0 \%$ of the examined guts of T. zillii. According to Fryer and Iles (1972), T. zillii has the ability to utilize higher plants as a source of food. This meets the cutting edge of its teeth adapted for such feeding habits. Shalloof and Khalifa (2009) emphasized the importance of plant as a major food resource in the stomach of O.niloticus.

Among the zooplankton, rotifers occurred in higher number of O.aureus and S.galilaeus guts (i.e. 40.0 and $60.0 \%$, respectively). El-Shabrawy et al. (2007) mentioned that, rotifers dominated the zooplankton groups forming about $87 \%$ of total zooplankton in Abu-Zaabal Lakes, and Brachionus plicatlis proved to be the most dominant species.

Examination of the diet of these species showed that, there was high percentage of sand particles in their stomachs comprising about 77.8, 60.0 and $24.0 \%$ in O.aureus, S.galilaeus and T.zillii respectively. Abdo, (2005) pointed out that, the increase in silicate concentration may be related to the nature and chemical composition of the basalt rocks in Abu-Zaabal Lakes. The ability to exploit different varieties of food makes O. aureus, T.zillii and S.galilaeus to be omnivorous, and so can be used for culture and rearing in this lake.

In conclusion, results of the present study show that:

1- It can be obtained marketable size of cichlid from Abu- Zaabal Lakes can be used as a big fish farm, for cichlid fish since maximum asymptotic lengths $\left(\mathrm{L}_{\infty}\right)$ $=34.59 ; 45.23 ; 39.88$ and $30.65 \mathrm{~cm}$ for O. niloticus ,O. aureus, T. zillii and $S$. galilaeus, respectively.

2- Sharp decrease in catch per unit effort $(\mathrm{Kg} /$ boat $)$, and change in species composition from 2005 to 2009 indicate successive changes in the ecology of the lakes, so studies must be carried out continually to investigate such ecological alternations.

3- Gut analysis of O. aureus, T. zillii and S. galilaeus in Abu-Zaabal Lakes revealed that, the major food items were detritus, diatoms, green algae, animal 
derivatives, sand particles and rotifers. This ability to exploit different varieties of food makes these species omnivorous and so can be used for culture and rearing in this lake.

\section{ACKNOWLEDGMENT}

This research was a part of a research project titled" Environmental evaluation of Abu-Zaabal Lakes and its usability as a fish farm", that was sponsored by the National Institute of Oceanography and Fisheries, Egypt. We are grateful to Prof. Mohammed Hassan Abdou, NIOF, Inland water branch, Cairo, Egypt.

\section{REFERENCES}

Abd-Ellah, R. G. (2003). On physical limnology of Abu Za baal Lakes, Egypt. Bull. Nat. Inst. Oceano. \& Fish. A.R.E., 29: 461-471.

Abdo, M. H. (2005). Physico-chemical characteristics of Abu Za baal ponds, Egypt. Egypt. J. Aquat. Res., 31(2): 1-15.

Amarasinghe, U. S. and Samarakoon, J. I. (1988). Some factors affecting contribution of cichlid species Etroplus suratensis and Tilapia rendalli to the gill net catches of a man made lake in Serilanka. Asian Fish. Sci., 2: 17-26.

Anene, A. (2005). Condition factor of four cichlid species of man- made lake in Imo State, Southeastern Nigeria. Turk. J. Fish. Aquat. Sci., 5: 43- 47.

Bagenal, T. and Tesch, F. W. (1978). Age and growth. In Methods for: assessment of fish production in fresh waters. IBP Handbook, No.3, $3^{\text {rd }}$ edn. pp. 101- 136. Blackwell Scientific Press, Oxford.

Drenner, R.W.; Vinyard, G. I.; Gophen, M. and Cornas, Mc. (1982). Feeding behaviour of the cichlid Sarotherodon galilaeus: Selective predation on Lake Kinneret zooplankton. Hydrobiologia , 87: 17- 20.

El-Basset, R. A. and Taylor, W. D. (2007). The zooplankton community of Lake Abu-Zaabal, a newly formed mining lake in Cairo, Egypt. African Journal of Aqua. Sci., 32: 185-192.

El-Gawady, M. M. (2002). Microbial pollution types in Manzala Lake. M.Sc. Thesis Mansoura Univ. Fac. Agric. Microbiol. Dept.

El-Mansy, A. I. (2005). Pathological conditions in Tilapia zillii Geravais, 1848 caught from Abo- Zaabal Lake, North Eastern of Cairo, Egypt. J. 
Egypt Soc. Environ. Develop. (D- Environmental Studies), 6(2):5788.

El-Mansy, A. I. (2009): Environmental evaluation of Abu-Zaabal Lakes and its usability as a fish farm. Internal report. NIOF, Egypt.

El-Shabrawy, G. M.; Sleem, S. H. and Ali, M. H. H. (2007). A preliminary study on zooplankton and macrobenthos in relation to some physical and chemical conditions at Abu Zabaal Ponds, Egypt. Egypt. J. Aquat. Biol. and Fish., 11: 635-653.

FAO (1980). Report of the Ad Hoc consultation on aquaculture research. FAO Fish. Rep. 238, FAO, Rome, 26pp.

Fryer, G. and Iles, T .D. (1972). The cichlid fishes of the great lakes of Africa: Their biology and evolution. Edinburg, Oliver and Boyed, 641 pp.

Javaid, M. Y. and Akram, M. (1972). The length-weight relationship and condition factor of seven fresh water fishes of Pakistan. Bull. Dep. Zool. Univ. Punjab, 6: 1- 27.

Johanson, S. J. S. and Jobling, M. (1989). The influence of feeding regime on growth and slaughter traits of cage- reared Atlantic salmon. Aquaculture International, 6: 1-17.

Hile, R. (1936). Age and growth of cisco, Leucichthys artedi (le Sueur) in the lakes of North- eastern highlands.Wisconsin. Bull. U. S. Bur. Fish. 48:211- 317 .

Hoff, J. G and Ibra, R. M. (1977). Factors affecting the seasonal abundance, composition and diversity of fishes in a southeastern New England estuary. East Etrplus Coast. Mar. Sci., 5: 665-678.

Hyslop, E. J. (1980). Stomach contents analysis- A review of methods and their application. J. Fish Biol., Southampton, 17: 411- 429.

Ibrahim, S. M.; Shalloof, K. A. Sh. and Salama, H. M. M. (2008). Effect of environmental conditions of Abu Zaabal Lake on some biological, histological and quality aspects of fish. Global Vetrinaria, 2: 257- 270.

Lee, R. (1920). A review of the methods of age and growth determination in fishes by means of their scales. Ministry of Agri. and Fish. Invest. $2^{\text {nd }}$ series, 4:1-132, London. 
Mahmoud, H. H. and Mazrouh, M. M. (2008). Biology and fisheries management of Tilapia species in Rosetta branch of the Nile River, Egypt. Egypt. J Aquat. Res., 30: 272- 285.

Martin, W. R. (1949). The mechanic of environmental control of body form in fishes.Univ. Toronto . Stud. Biol. , 58: 1- 91.

Mohamed, A. M. H. (2005). Ecological studies on phytoplankton composition of newly formed aquatic depressions at Abou-Zaabal quarries region. Master Science Thesis. Faculty of Science, Al-Azhar University, Cairo, Egypt.

Mohamed, F. A. S. and Gad, N .S. (2005). Distribution of some heavy metals in tissues of Oreochromis niloticus, Tilapia zillii and Clarias lazera from Abu Za Baal lakes and their impacts on some biochemical parameters and on the histological structure of some organs. Egypt. J. Aquat. Biol. \& Fisher., 9(1): 41-80.

Oni, S. K.; Olayemi, J. Y. and Adegboye, J. D. (1983). Comparative physiology of three ecologically distinct fresh water fishes, Alestes nurse Ruppell, Synodontis schall Bloch and S. Schneider and T.zillii Gervais. J. Fish Biol., 22: 105- 109.

Oronsaye, C. G. and Nakpodia, F. A. (2005). A comparative study of the food and feeding habits of Chrysichthys nigrodigitatus and Brycinus nurse in a tropical river. Pak. J. Sci. Ind. Res., 48: 118-121.

Oso, J. A.; Ayodele, I. A. and Fagbuaro, O. (2006). Food and feeding habits of Oreochromis niloticus (L.) and Sarotherodon galilaeus (L.) in a Tropical Reservoir. World J. Zool., 1: 118-121.

Oviatt, C. A. and Nixon. S. W. (1973). The demersal fish of Narragansett Bay: an analysis of community structure, distribution and abundance .Est. Coast. Mar., 1: 361-378.

Pauly, D. (1993). Editorial . Fish byte section. Naga, The ICLARM Q, 16: 26.

Pervin, M. R. and Mortuza, M. G. (2008). Notes on length-weight relationship and condition factor of fresh water fish, Labeo boga (Hamilton) (Cypriniformes: Cyprinidae).Univ. J. Rajshahi Univ., 27:97- 98. 
Rabeh, S. A. and Azab, E. A. (2006). Bacterial indicators of both sewage pollution and trophic status in Abu Za'baal Lakes, Egypt. Res. J. Microbiol., 1: 480-491.

Saliu, J. K.; Joy, O. and Catherine, O. (2007). Condition factor, Fat and protein content of five fish species in Lekki Lagoon, Nigeria. Life Science J., 4: 54- 57.

Shafi, M. and Quddus, M. M. (1974). Length-weight relationship and condition factor in Hilsa ilisha (Hamilton) (Clupeiforms: Clupeidae).Bangladesh J.Zool., 2: 179- 185.

Shalloof, K. A. Sh. and Khalifa, N. (2009). Stomach contents and feeding habits of Oreochromis niloticus (L.) from Abu-Zaabal Lakes, Egypt. World Applied Sci. J., 6: 1-5.

Shalloof, K. A. Sh. and Salama, H. M. (2008). Investigations on some aspects of reproductive biology in Oreochromis niloticus (Linnaeus, 1757) inhabited Abu-Zaabal Lake, Egypt. Global Vetrinaria, 2: 351- 359.

Vinyard, G. L.; Drenner, R. W.; Gophen, M.; Pollingher, U; Winkelman, D. L. and Hambright, D. K. (1987). Experimental study of the plankton community. Impact of two omnivorous filter feeding cichlids, Tilapia galilaea and Tilapia aurea.Cand.J.Aquat.Sci., 45: 685- 690.

Walford, L. A. (1946). A new graphic method of describing the growth of animals. Biol. Bull., 90: 141- 147.

Weatherley, A. H. and Gill, H. S. (1987). The biology of fish growth. Academic Press, London.

Weng, H. T. (1988). Trawl- caught fish in Moreton Bay. Australia :Value, Dominanca, Diversity and Faunal zonation. Asian Fish. Sc., 2: 43-57.

Wooten, R. J. (1990). Ecology of teleost fishes. Kluwer Academic Publ., London. pp. 404.

Zafar, M.; Mussaddeq, Y.; Akhter, Sh. and Sultan, A. (2003). Weight- length and condition factor relationship of Thaila, Catla catla from Rawal Dam Islamabad, Pakistan. Pakistan J. of Biol. Sci., 6: 1532- 1534. 